\title{
Calorie restriction and sirtuins revisited
}

\author{
Leonard Guarente ${ }^{1}$ \\ Department of Biology, Glenn Laboratory for the Science of Aging, Massachusetts Institute of Technology, \\ Cambridge, Massachusetts 02139, USA
}

\begin{abstract}
Calorie or dietary restriction $(\mathrm{CR})$ has attracted attention because it is the oldest and most robust way to extend rodent life span. The idea that the nutrient sensors, termed sirtuins, might mediate effects of $C R$ was proposed 13 years ago and has been challenged in the intervening years. This review addresses these challenges and draws from a great body of new data in the sirtuin field that shows a systematic redirection of mammalian physiology in response to diet by sirtuins. The prospects for drugs that can deliver at least a subset of the benefits of $C R$ seems very real.
\end{abstract}

A review published previously in Genes \& Development (Guarente 2000) stated the hypothesis that calorie restriction (CR) slowed aging and the accompanying decline in health by activating yeast Sir2p and its homologs in higher organisms, now collectively termed sirtuins. This active mechanism for $\mathrm{CR}$ required regulation by nutrient sensors and contrasted with previous passive models; for example, that less food slowed the accumulation of oxidative damage. The idea that CR was thus regulated arose from the discovery that sirtuins were NAD-dependent deacetylases (Imai et al. 2000), which also gave rise to replicative longevity in yeast (Kaeberlein et al. 1999). Three years later, small molecules that activated the mammalian sirtuin SIRT1 were described (Howitz et al. 2003), suggesting that health-promoting CR mimetic drugs might be possible. Since the 2000 review, thousands of studies on sirtuins and activating compounds like resveratrol have been published along with some challenging data, and this large body of information now prompts a re-evaluation of the robustness of the original hypothesis. The first part of this review discusses challenges to the sirtuin/CR hypothesis that have arisen over the years and how more recent data address many of these concerns. The latter parts describe links between the many cellular and molecular functions of mammalian sirtuins and the critical tissue-autonomous and systemic physiological adaptations triggered by CR. This does not attempt to be a comprehensive review of all findings in the area of CR, and I apologize to those whose work is not described.

[Keywords: CR mimetics; calorie restriction; sirtuins]

${ }^{1}$ Correspondence

E-mail leng@mit.edu

Article is online at http://www.genesdev.org/cgi/doi/10.1101/gad.227439.113. Freely available online through the Genes \& Development Open Access option.

\section{Toward the resolution of discordances}

\section{Sirtuins and aging}

Perhaps the greatest challenge to the idea that sirtuins mediate effects of CR was a study describing the failure to observe extension of life span in worms or flies transgenic for the corresponding SIR2 orthologs after controlling for genetic background (Burnett et al. 2011). These findings contradicted other, earlier studies that showed extension of life span in transgenic worms (Tissenbaum and Guarente 2001; Viswanathan et al. 2005; Berdichevsky et al. 2006) and flies (Rogina and Helfand 2004; Wood et al. 2004; Bauer et al. 2009). In fact, a subset of these earlier studies did control for genetic background (e.g., Bauer et al. 2009), creating conflicting claims about the role of sirtuins in aging.

Recently, a group of papers re-examined the effects of sirtuins on life spans in different organisms and reinforced the idea that they are of central importance (Fig. 1). In budding yeast, one study underscored the established importance of SIR2 in replicative aging (Stumpferl et al. 2012). Two highly divergent yeast strains (a laboratory strain and a clinical isolate) were crossed, and a genome-wide quantitative trait locus (QTL) analysis pinpointed those genetic differences responsible for the difference in replicative life span. Indeed, the most important locus was SIR2, explaining more than half of the difference in the replicative life span between the strains (due to five codon differences between the SIR2 alleles).

In flies, the critical role of Drosophila Sir2 (dSir2) was revealed by tissue-specific manipulation of the gene under an inducible promoter (Banerjee et al. 2012), a more specific system compared with the constitutive wholebody overexpression at a single dose in the prior study (Burnett et al. 2011). Overexpression of dSir2 in the fat body extended the life span of flies on the normal diet. This fits well with earlier findings that the fat body is a critical determinant of Drosophila life span (Giannakou et al. 2004; Hwangbo et al. 2004). In a second experiment, Banerjee et al. (2012) found that deletion of $d$ Sir2 in the fat body abolished the extension of life span by a CR-like

(c) 2013 Guarente This article, published in Genes \& Development, is available under a Creative Commons License (Attribution-NonCommercial 3.0 Unported), as described at http://creativecommons.org/licenses/ by-nc/3.0/. 


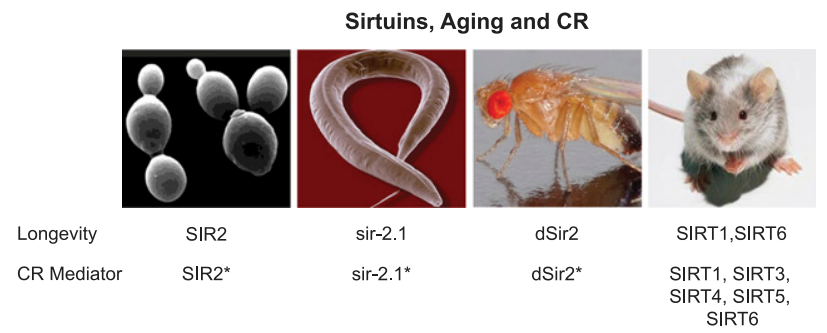

Figure 1. Sirtuins, longevity, and CR. The indicated sirtuins have been shown to promote longevity when activated in yeast, worms, flies, and mice, as discussed in the text. The requirement for these sirtuins for the effects of CR is also shown. The asterisks indicate that different laboratories and protocols have elicited different requirements in the lower organisms; i.e., some studies show a requirement, and others do not.

protocol. This latter experiment illustrates the role of dSir2 in mediating dietary effects on longevity, discussed in greater detail below. A second recent study confirms that dSir2 overexpression increases the life span in flies (Hoffmann et al. 2013).

In worms, two studies concurrent with Burnett et al. (2011) showed that increasing the dose of Caenorhabditis elegans sir-2.1 did indeed extend the life span (Rizki et al. 2011; Viswanathan and Guarente 2011), although not to the extreme level previously reported (Tissenbaum and Guarente 2001). The 2001 study was complicated by an unrecognized, unlinked mutation that made the extension appear larger. In the past year, three additional studies implicate sir-2.1 in worm longevity. First, the dauer-inducing natural products of the worm, ascarosides, were shown to extend worm life span in a pathway requiring SIR-2.1 (Ludewig et al. 2013). Second, a recent study confirmed that SIR-2.1 overexpression extends life span (Mouchiroud et al. 2013). In addition, boosting internal NAD levels could also extend the life span via sir-2.1. NAD/SIR-2.1 induced two distinct longevity pathways; one involved insulin-like signaling and the FOXO homolog DAF-16, and the other involved the mitochondrial unfolded protein response resulting from an imbalance between nuclear and mitochondrial gene expression. Importantly, this study also pinpoints a possible mechanism of normal aging-NAD depletion by chronic DNA damage-induced PARP activation. In a third study, life span extension in SIR-2.1-overexpressing strains was again confirmed by Ristow and colleagues (Schmeisser et al. 2013) using strains from Burnett et al. (2011) as well as Viswanathan and Guarente (2011).

In mammals, Kanfi et al. (2012) showed that two transgenic mouse lines overexpressing the mammalian SIRT6 had significantly extended male life spans. Mammals have seven sirtuins, SIRT1-7 (Fig. 2). SIRT1, SIRT6, and SIRT7 are nuclear; SIRT3, SIRT4, and SIRT5 are mitochondrial; and SIRT2 is cytoplasmic. In a very recent study, brainspecific overexpression of SIRT1 was also shown to extend the life span (Satoh et al. 2013). The failure of whole-body SIRT1 overexpression to extend the life span may be due to untoward effects on cancer, which counteract the observed slowing of aging in these mice (Herranz et al. 2010). Finally, in humans, a link between SNPs at the SIRT3 locus and longevity has also been described (Albani et al. 2013). All told, the above body of work strongly supports the proposal that sirtuins are conserved mediators of longevity.

\section{Sirtuins and dietary restriction in lower organisms}

$\mathrm{CR}$ in rodents was first shown to extend life span in the 1930s (McCay et al. 1935) and is a very specific regimen-a 30\%-40\% reduction in the ad libitum levels of chow intake. We originally attempted to apply the concept of CR to yeast by mutating nutrient-sensing pathways or providing $0.5 \%$ glucose instead of the usual $2 \%$ and found that the replicative life span was extended (Fig. 1; Lin et al. 2000, 2002). Importantly, extension was

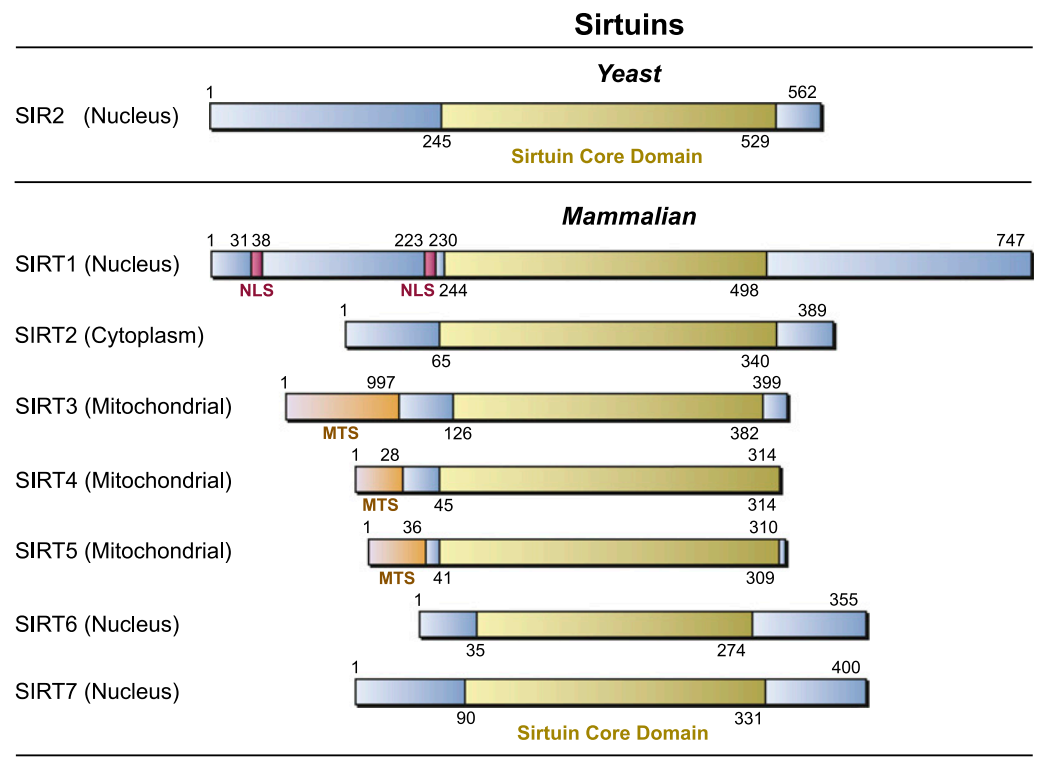

Figure 2. Primary structure of sirtuins. The seven mammalian sirtuins (SIRT1-7) are aligned with yeast Sir2p (yeast has four other SIR2 paralogs, HST1-4). The conserved, catalytic domain that all sirtuins have in common is in yellow. Nuclear localization sequences (NLSs) and mitochondrial targeting sequences (MTSs) are also indicated. Numbers refer to amino acid residues in the proteins. 
abolished when SIR2 was knocked out. However, other studies, which generally (but not always) used a more severe limitation of the glucose, found life span extension that was not SIR2-dependent (Kaeberlein et al. 2004). Consistent with a role of SIR2 in CR, the NAD salvage pathway enzyme Pnclp was shown to be up-regulated by $0.5 \% \mathrm{CR}$ and required for longevity (Anderson et al. 2003). Furthermore, the SIR2 paralog HST2 was implicated in CR at the extreme concentrations of glucose (Lamming et al. 2005). As discussed below, subtle differences in media or other laboratory conditions may account for observed experimental differences.

In C. elegans, both genetic and physiological regimens of CR were contrived, and life span extension by one required sir-2.1 (Narasimhan et al. 2009), but extension by others did not (e.g., Bishop and Guarente 2007). Similarly, in flies, a limitation of the yeast extract in the diet was shown to extend the life span. In two studies, dSir2 was essential (Rogina and Helfand 2004; Banerjee et al. 2012), but in another, it was not (Burnett et al. 2011). How can we interpret these disparate findings? We now know that metazoans have multiple nutrient-sensing pathways that can affect the life span (e.g., insulin signaling) (Kenyon 2010), TOR (Johnson et al. 2013), AMP kinase (Kahn et al. 2005), and sirtuins (Guarente 2000). Any variability in laboratory conditions might favor signaling through different subsets of these pathways, explaining the reported differences in the genetic requirements for CR in lower organisms (Speakman and Mitchell 2011).

\section{SIRT1 activators}

Finally, putative SIRT1-activating compounds (resveratrol and newer, synthetic STACs) were reported to activate the enzyme in vitro by lowering its $\mathrm{Km}$ for substrate (Howitz et al. 2003) and also elicit health benefits in mice, especially in animals exposed to the high-fat diet (Baur et al. 2006; Lagouge et al. 2006; Milne et al. 2007). However, the proposed mechanism of both resveratrol and newer STACs was challenged because activation appeared to require the presence of a fluorescent tag on the substrate peptide used in vitro (Kaeberlein et al. 2005). In addition, resveratrol was suggested to activate SIRT1 in vivo indirectly by binding to phosphodiesterases and triggering cAMP signaling to activate SIRT1 (Park et al. 2012). Three subsequent studies provide strong evidence that these compounds really work by directly activating SIRT1. First, activation can, in fact, be demonstrated using peptide substrates without any fluorescent conjugate (Dai et al. 2010). Importantly, the presence of aromatic amino acid side chains at residues positioned near the deacetylated lysine was required, suggesting a substrate specificity for activation foreshadowed by the earlier apparent requirement for the fluorescent tags. Second, acute deletion of SIRT1 in adult mice prevented many of the physiological effects of resveratrol and other STACs (Price et al. 2012). Third, a single mutation in SIRT1 abolished the ability of resveratrol and all 117 other STACs tested to activate the enzyme in vitro or promote the canonical physiological changes in cells (Hubbard et al. 2013). This mutation lies adjacent to but outside of the catalytic domain and is thought to define an allosteric site in the enzyme for activation by small molecules. At present, it is difficult to interpret all of these findings in any model other than direct activation of SIRT1 by resveratrol and other STACs. Of course, the dose of resveratrol or other STACs may affect whether additional targets are also engaged in vivo.

\section{Sirtuins and $\mathrm{CR}$ in mice}

\section{General effects}

CR studies in mice have the advantage of being more standardized than dietary studies in lower organisms; e.g., many of these experiments use C57BL/6 mice under a $30 \%$ limitation of the ad libitum consumption of chow food. The lines of evidence that sirtuins mediate effects of CR in mammals are many. First, the substrates targeted by sirtuins SIRT1, SIRT3, SIRT4, SIRT5, and SIRT6 (detailed in the next section) closely define those pathways at the heart of the metabolic shift induced by CR. Second, $\mathrm{CR}$ induces the expression levels of at least a subset of the sirtuins-SIRT1 (Cohen et al. 2004), SIRT3 (Lombard et al. 2007), and SIRT5 (Nakagawa et al. 2009). SIRT1 is also induced by CR in humans (Civitarese et al. 2007). Reciprocally, a high-fat diet leads to the loss of SIRT1 in mice (Chalkiadaki and Guarente 2012), and obesity has the same effect in humans (Pedersen et al. 2008; Costa Cdos et al. 2010). Third, loss-of-function mutation of specific sirtuins ablates specific outputs of CR. For example, knocking out SIRT1 abolishes changes in physical activity (Chen et al. 2005), and brain-specific ablation has a similar effect on the somatotrophic axis (growth hormone/IGF-1) (Cohen et al. 2009). In addition, SIRT1 knockout mice do not live longer on a CR diet (Boily et al. 2008; Mercken et al. 2013). Knocking out the mitochondrial SIRT3 prevents the protective effect of CR against hearing loss (Someya et al. 2010). In this case, SIRT3 is required for CR to mitigate oxidative damage in crucial neurons of the inner ear. Deletion of SIRT5 prevents the up-regulation of the urea cycle, which is required to reduce blood ammonia when amino acids serve as energy sources (Nakagawa et al. 2009).

Fourth, transgenic overexpression of SIRT1 or STACs mitigates disease syndromes much like $\mathrm{CR}_{\text {; }}$ these include diabetes, neurodegenerative diseases, liver steatosis, bone loss, and inflammation (Baur et al. 2006; Lagouge et al. 2006; Bordone et al. 2007; Pfluger et al. 2008; Herranz et al. 2010; Guarente 2011). Tissues likely responsible for these effects are discussed in another section below, but one aspect may involve a positive effect of SIRT1 on insulin secretion by pancreatic $\beta$ cells (Moynihan et al. 2005; Bordone et al. 2006). Conversely, compromised sirtuin activity contributes to metabolic syndrome and diabetes in mice and humans (Hirschey et al. 2011; Chalkiadaki and Guarente 2012; Biason-Lauber et al. 2013). Fifth, SIRT1 activators like resveratrol exert effects that overlap those of $\mathrm{CR}$ at the level of whole-animal 
physiology (Lam et al. 2013) or transcriptional profiling (Barger et al. 2008). All told, one may conclude that this is the most complete set of evidence for the involvement of any genetic pathway in CR.

\section{Cellular effects}

Perhaps the most direct indication that sirtuins play an important role in the physiological adaptation to $\mathrm{CR}$ comes from a more detailed analysis of their substrates and physiological effects. Two hallmarks of CR are metabolic reprogramming to oxidative metabolism (to gain the most possible energy from fuel sources) and resistance to stress, particularly oxidative stress. This section considers general cellular effects of sirtuins on these hallmarks, and the subsequent section examines tissue-specific effects.

SIRT1 plays a central role in inducing mitochondrial biogenesis, stress tolerance, and fat metabolism. This sirtuin deacetylates PGC- $1 \alpha$ (Rodgers et al. 2005; GerhartHines et al. 2007), FOXO1 (Brunet et al. 2004; Motta et al. 2004), and PPAR $\alpha$ (Purushotham et al. 2009). In this regard, SIRT1 activity is tightly linked to AMP kinase (AMPK) (Feige et al. 2008; Fulco et al. 2008), since AMPK drives expression of the NAD synthetic enzyme NAMPT (Canto et al. 2009, 2010), and SIRT1 deacetylates and activates the AMPK activator kinase LKB1 (Hou et al. 2008; Lan et al. 2008). At the same time, SIRT1 turns down glycolytic metabolism by deacetylating glycolytic enzymes (Hallows et al. 2012) and one of their key transcriptional inducers, HIF-1 $\alpha$ (Lim et al. 2010). One must assume that repressing HIF- $1 \alpha$ is especially important, since SIRT3 and SIRT6 also target this pathway. SIRT3 reduces reactive oxygen species (ROS) production by mitochondria, thus blunting HIF- $1 \alpha$ induction as well as generally reducing the ROS burden to cells (Bell et al. 2011; Finley et al. 2011). SIRT6 corepresses HIF-1 $\alpha$ target genes by deacetylating histones at those loci (Zhong et al. 2010).

The metabolic shift away from glycolysis and toward mitochondria along with the accompanying stress resistance are reinforced by the deacetylation and desuccinylation of mitochondrial proteins by SIRT3 (Lombard et al. 2007) and SIRT5 (Du et al. 2011; Peng et al. 2011), respectively. Mitochondrial targets thus activated by these sirtuins include superoxide dismutase 2 (Qiu et al. 2010; Tao et al. 2010) and metabolic enzymes for fatty acid oxidation (Hirschey et al. 2010), the urea cycle (Nakagawa et al. 2009; Hallows et al. 2011), and acetate metabolism (Hallows et al. 2006; Schwer et al. 2006). Interestingly, the third mitochondrial sirtuin, SIRT4, seems to be wired oppositely to SIRT3 and SIRT5; i.e., its expression goes down in CR. This also makes sense because SIRT4 ADP-ribosylates and represses glutamate dehydrogenase (Haigis et al. 2006), the gateway for glutamine and glutamate to enter the TCA cycle and central metabolism to provide energy during CR.

These actions of SIRT1, SIRT3, SIRT4, and SIRT6 are relevant to the Warburg effect, in which cancer cells show a massive up-regulation of glycolysis and glutaminolysis, thereby suggesting tumor suppressor functions. Indeed, loss of SIRT3 (Finley et al. 2011) or SIRT6 (Sebastian et al. 2012), which would induce glycolysis, or loss of SIRT4, which would induce glutaminolysis, has been found in many tumors (Jeong et al. 2013). Interestingly, SIRT4 is the sirtuin most highly induced by DNA damage and impedes glutamine entry into metabolism, raising the possibility that a "glutamine checkpoint" may play a tumor suppressor role by limiting growth of precancerous cells to allow repair of damage (Jeong et al. 2013). A second study also implicates SIRT4 in cancer suppression and shows that levels of this sirtuin are regulated by mTORC1 (Csibi et al. 2013). One should note for SIRT1, however, that evidence for both a tumor prevention function (e.g., Firestein et al. 2008) and tumor enhancement function in established tumors (e.g., Li et al. 2013) has been reported.

Besides HIF-1 $\alpha$, the only known target of three or more sirtuins is NF- $\mathrm{B}$, involved in a proinflammatory arm of the immune response. p65 of this transcription factor is deacetylated and repressed by SIRT1 (Yeung et al. 2004) and SIRT2 (Rothgiesser et al. 2010), and histones at NFкB-regulated genes are deacetylated by SIRT6 (Kawahara et al. 2009) to reinforce repression. These sirtuin functions may help explain the global anti-inflammatory effect of CR, which may be an important mechanism by which this diet slows aging. Indeed, NF- $\mathrm{B}$ activation has been linked to aging (Adler et al. 2007), a topic explored further below.

\section{Effects in specific tissues}

It is clear that the effects of CR must be a coordinated, systemic response, prompting the question of what tissues are most important and how they interact. The next section reviews roles of SIRT1 in various tissues, as outlined in Figure 3, which may help explain the organismal protection conferred by this diet.

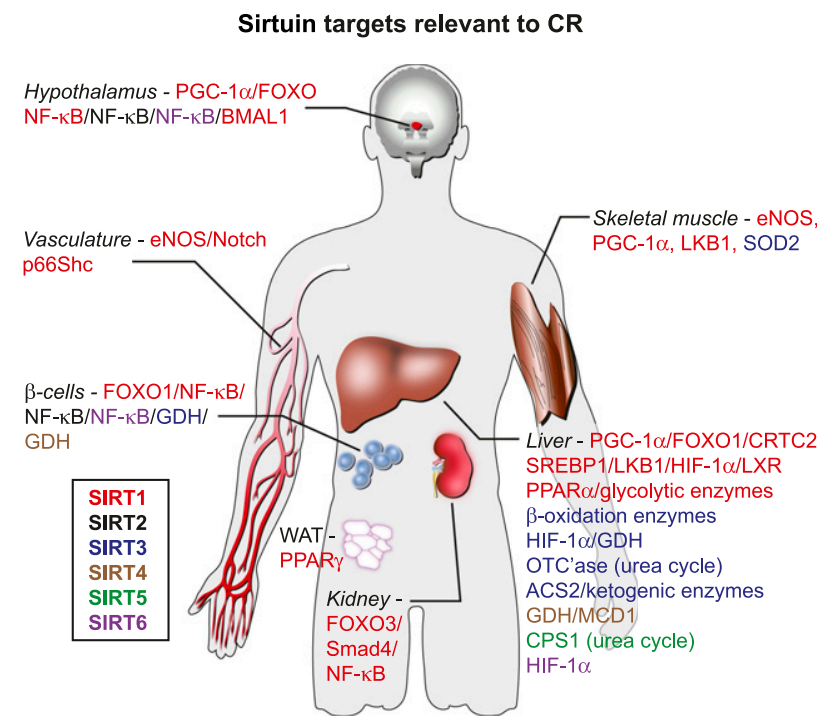

Figure 3. Sirtuin targets in different tissues relevant to CR. The figure shows validated sirtuin targets in seven tissues. The color coding of sirtuins is shown in the key. 


\section{Hypothalamus}

The hypothalamus contains different groups of neurons that control much of mammalian physiology, including feeding behavior, energy expenditure, physical activity, body temperature, and central circadian control (Coppari 2012). It was originally inferred that this brain region may play a key signaling role in CR from studies in worms, in which ablation of two neurons prevented the increased energy expenditure and longevity conferred by a CR-like protocol (Bishop and Guarente 2007). Many hypothalamic functions of SIRT1 have been reported (Fig. 4). A plausible role of hypothalamic SIRT1 in mammals was first suggested by the observation that levels of this sirtuin in this brain region change with the diet (Ramadori et al. 2008). Further evidence is the finding that brain depletion of SIRT1 prevents CR regulation of the somatatrophic axis (Cohen et al. 2009). Indeed, genetic manipulation of SIRT1 protein levels in the hypothalamus affects feeding behavior, although the direction of the changes and the effects of the diet on these changes are not fully consistent from study to study (Cakir et al. 2009; Sasaki et al. 2010). Nonetheless, the weight of evidence indicates that SIRT1 in the agouti-related peptide-producing neurons (AgRPs) controls the response to the gut hormone ghrelin and feeding behavior (Dietrich et al. 2010, 2012; Sasaki et al. 2010). In addition, SIRT1 in the ventromedial hypothalamic (VMH) neurons determines physiological outputs to ghrelin signaling (Velasquez et al. 2011; Porteiro et al. 2013). SIRT1 in the dorsomedial hypothalamus (DMH) and lateral hypothalamus (LH) is induced by CR and mediates outputs such as physical activity and body temperature by determining the levels of the orexin receptor 2 (Satoh et al. 2010). Correspondingly, SIRT1 in the pro-opiomelanocortin (POMC) neurons (Ramadori et al. 2010) protects against metabolic decline induced by high-fat diets. As a final proof of principle, administering resveratrol directly to the CNS of rodents mediates insulin sensitivity, and this effect is abolished by knocking down SIRT1 expression in the hypothalamus (Knight et al. 2011).

Another hypothalamic region of importance is the suprachiasmatic nucleus (SCN), which determines central circadian control of metabolism and other aspects of

\section{SIRT1 Functions in Hypothalamus}

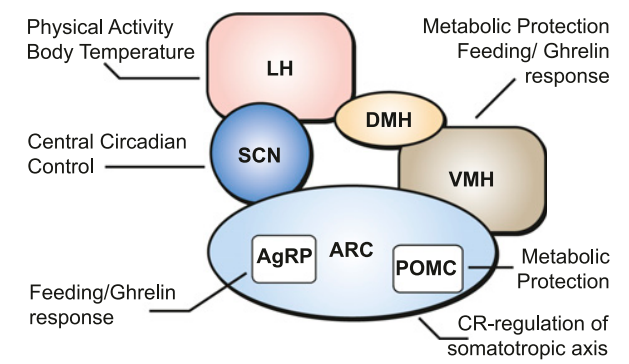

Figure 4. SIRT1 Functions in the hypothalamus. The indicated hypothalamic regions are the arcuate nucleus (ARC), agoutirelated peptide-producing neurons (AgRPs), pro-opiomelanocortin neurons (POMCs), ventromedial hypothalamus (VMH), dorsomedial hypothalamus (DMH), lateral hypothalamus (LH), and suprachiasmatic nucleus (SCN). physiology in addition to the sleep-wake cycle. The importance of circadian control in health maintenance is indicated by the negative consequences of circadian disruptions in humans or mutations in components of the clock, first suggested by Pittendrigh and Minis (1972). Intriguingly, mice with intrinsic circadian periods (the period revealed in all-dark conditions) very close to $24 \mathrm{~h}$ turn out to be the longest lived when housed in a $12 \mathrm{~h}$ light/12 h dark cycle (Wyse et al. 2010; Libert et al. 2012). These findings suggest that re-entrainment of the central clock by light every $24 \mathrm{~h}$ in mice whose intrinsic clocks deviate significantly from $24 \mathrm{~h}$ imposes a daily demand for a functional central circadian clock. Any loss in this function-for example, during aging (see below)—would trigger mistiming of metabolic pathways with negative affects on health and youthfulness.

SIRT1 was first linked to circadian control via the peripheral and autonomous clock in the liver. In this tissue, SIRT1 deacetylates circadian clock proteins BMAL1 and PER2 (Asher et al. 2008; Nakahata et al. 2008) to influence their function. In the liver, the clock also regulates NAMPT, rendering sirtuin activity circadian and providing a link between the clock and metabolism (Nakahata et al. 2009; Ramsey et al. 2009). Interestingly, SIRT1 has been shown recently to also control central circadian function in the brain by amplifying expression of BMAL1 (Chang and Guarente 2013). Importantly, SIRT1 levels decline in the SCN of aged mice compared with young controls. This decline is concomitant with the reduction of many of the components of the circadian clock, presumably triggering the degradation of central circadian function with aging (Valentinuzzi et al. 1997). Remarkably, overexpressing SIRT1 in the brain blunts the effects of aging on circadian function, and deletion of SIRT1 compromises function in young animals. SIRT1 deacetylates PGC- $1 \alpha$ in neurons to increase activation of BMAL transcription. Thus, a loop of SIRT1, PGC- $1 \alpha$, and NAMPT amplifies the expression of circadian clock proteins and assures proper central circadian function in the SCN (Chang and Guarente 2013). The fact that SIRT1 appears to be the Achilles heel in aging suggests that brain targeted sirtuin drugs may help maintain central circadian function and mitigate health decline.

Finally, a recent study directly illustrates the importance of the hypothalamus (and NF-kB) in mammalian aging. Tissue-specific deletion of the inhibitor of the NF- $\mathrm{B}$ inhibitor I- $\mathrm{B}$ results in the expected reduction in NF- $\mathrm{KB}$ activity in hypothalamic neurons and significantly extends the life span of mice (Zhang et al. 2013). Satoh et al. (2013) also conclude that SIRT1 in the hypothalamus is key to the observed extension of life span in transgenic mice by virtue of its activation of the orexin type 2 receptor in the LH and DMH. In summary, it is now emerging from numerous lines of evidence that the hypothalamus may play a dominant role in mammalian aging, and SIRT1 is an important regulator in this compartment.

Many other studies reviewed elsewhere (Herskovits and Guarente 2013) show that SIRT1 functions in other brain regions. For example, SIRT1 protects against 
neurodegenerative diseases in the cortex and striatum (Kim et al. 2007; Donmez et al. 2010; Min et al. 2010; Jeong et al. 2011; Jiang et al. 2011) and enhances learning and memory in the hippocampus (Gao et al. 2010; Michan et al. 2010). Since healthy physiological function driven by all of these regions deteriorates with aging, sustaining SIRT1 activity may be generally important for brain maintenance.

\section{White adipose tissue (WAT)}

SIRT1 and NAD ${ }^{+}$levels are induced in WAT of CR mice (Chen et al. 2008). Conversely, SIRT1 levels are reduced in white fat in obese mice (Chalkiadaki and Guarente 2012) and obese humans (Pedersen et al. 2008; Costa Cdos et al. 2010). One possible mechanism for loss of SIRT1 in obese animals is suggested by the finding that a high-fat diet in mice triggers cleavage of SIRT1 in WAT by caspase 1 of the inflammasome (Chalkiadaki and Guarente 2012). Mice genetically knocked out for SIRT1 in WAT are predisposed to diabetes, likely because the first "hit" toward diabetes (i.e., SIRT1 loss in WAT) has already taken place. Interestingly, SIRT2 also plays an important functional role in adipocyte biology by regulating differentiation of preadipocytes (Jing et al. 2007).

Other functional data are consistent with the hypothesis that SIRT1 in WAT promotes metabolic health by causing fat reduction in these depots. SIRT1 promotes fat mobilization from WAT to blood, for example, during fasting (Picard et al. 2004), to facilitate its oxidation in the liver and muscle. SIRT1 also drives the browning of white fat cells (Qiang et al. 2012), which would trigger fat oxidation in situ. Consistent with these functions, inhibition of SIRT1 in WAT is associated with macrophage recruitment and inflammation (Gillum et al. 2011). One target for deacetylation by SIRT1 in WAT is the nuclear receptor PPAR $\gamma$. SIRT1 alters gene expression of a subset of PPAR $\gamma$ target genes (Wang et al. 2008) and restrains differentiation of preadipocyte precursor cells (Picard et al. 2004). Last, SIRT1 transgenic mice show higher levels of the insulin-sensitizing adipokine adiponectin (Banks et al. 2008). The expanded role of sirtuins in adipokine production and endocrine cross-talk between WAT and the hypothalamus remains a fascinating area to explore.

\section{Liver}

In the liver, SIRT1 has numerous deacetylation targets that affect gluconeogenesis and fat homeostasis. Many of these deacetylation events have opposing effects, revealing the complexity of SIRT1 function in this tissue. For example, SIRT1 deacetylates two coactivators that drive gluconeogenesis: PGC- $1 \alpha$ to activate it (Rodgers et al. 2005) and CRTC2 to trigger its ubiquitination and degradation (Liu et al. 2008). It is thought that SIRT1 thus stages a temporal shift during fasting by switching gluconeogenesis from an early CRTC2-driven mechanism to a later mechanism driven by the other SIRT1 target, PGC- $1 \alpha$. SIRT1 expression declines at the time of the shift due to the fact that the SIRT1 promoter itself is regulated by CRTC2 (via the transcription factor CREB)
(Noriega et al. 2011). The decline in CRTC2 (and correspondingly SIRT1) may set a proper, lower activity level of the SIRT1 substrate PGC-1 $\alpha$ during the later stage of fasting.

With regard to fat homeostasis, SIRT1 deacetylates the nuclear receptor LXR (Li et al. 2007) to activate the SREBP1 gene for synthesis. However, SIRT1 also deacetylates SREBP1 itself to repress its activity (Ponugoti et al. 2010; Walker et al. 2010). Other substrates of SIRT1 include the nuclear receptor FXR for bile synthesis (Kemper et al. 2009) and LKB1 linking SIRT1 and AMPK (Hou et al. 2008; Lan et al. 2008), as discussed above. What is the net effect of summing the various SIRT1 hepatic activities? Numerous studies have examined the role of hepatic SIRT1 under different dietary conditions. Most studies show that liver-specific deletion of SIRT1 triggers physiological hypersensitivity to a high-fat diet (You et al. 2008; Erion et al. 2009; Purushotham et al. 2009; Wang et al. 2010, 2011; Xu et al. 2010; but an exception is Chen et al. 2008), while overexpression gives protection against steatosis ( $\mathrm{Li}$ et al. 2011b). Consistent with this idea, high-fat diet-induced inflammation triggers phosphorylation of SIRT1 by JNK1 kinase, leading to its degradation (Gao et al. 2011), reminiscent of what is observed in WAT.

Liver SIRT4 again appears to oppose SIRT1, since its deletion protects against high-fat diet-induced steatosis (Nasrin et al. 2010). This may be because SIRT4 deacetylates and inhibits malonyl CoA decarboxylase 1 (MCD1), which converts malonyl CoA to acetyl CoA (Laurent et al. 2013). Thus, SIRT4 deletion would prevent the accumulation of malonyl CoA, the key precursor for fat synthesis, as would the reduction in SIRT4 levels in CR. Finally, hepatic SIRT6, like SIRT1, appears to be protective, since two studies show that its deletion sensitizes animals to steatosis (Kim et al. 2010; Dominy et al. 2012).

\section{Heart and skeletal muscle}

Many studies suggest that CR, exercise, and resveratrol induce mitochondrial biogenesis and increased stress tolerance in the skeletal muscle of mice and humans to improve physiology systemically (Baur et al. 2006; Lagouge et al. 2006; Feige et al. 2008; Koltai et al. 2010). At least three pathways have been implicated in mediating these effects. First, the activity of the nitric oxide synthase expressed in skeletal muscle (eNOS) is induced by CR in mice and humans (Nisoli et al. 2005; Civitarese et al. 2007). Since SIRT1 is known to deacetylate and activate eNOS (Mattagajasingh et al. 2007), the induction of this sirtuin in CR muscle can explain this chain of events. Importantly, eNOS ${ }^{-1-}$ mice do not show the induction of mitochondria by CR (Nisoli et al. 2005). Second, the deacetylation of PGC- $1 \alpha$ is also induced by $\mathrm{CR}$ or resveratrol and also drives mitochondrial biogenesis (Rodgers et al. 2005; Gerhart-Hines et al. 2007). Third, the CR-induced adipokine adiponectin binds to its receptor in muscle and stimulates the SIRT1/AMPK axis by causing $\mathrm{Ca}^{++}$release and activation of the AMPK 
kinase calmodulin-dependent protein kinase (Iwabu et al. 2010). This pathway may also be triggered by exercise (Iwabu et al. 2010). The effects of glucose on cultured skeletal muscle cells depend on the interaction of SIRT1 with AMPK (Fulco et al. 2008; Canto et al. 2010) and FOXO1 (Hariharan et al. 2010). Not surprisingly, tissuespecific knockout of SIRT1 in skeletal muscle blunts physiological changes induced by CR (Schenk et al. 2011).

With respect to the heart, studies with gain-of-function or loss-of-function mice indicate a protective role of SIRT1 against oxidative stress; for example, in ischemia/ reperfusion challenges (Hsu et al. 2010; Tanno et al. 2010). SIRT1 can also protect against hypertrophy at moderate levels of cardiac-specific overexpression but appears to be deleterious at higher levels (Alcendor et al. 2007). Protection against hypertrophy may involve a pathway including PPAR $\alpha$ and fat oxidation (Planavila et al. 2011), although, surprisingly, one study showed that haploinsufficiency of SIRT1 or PPAR $\alpha$ protected against hypertrophy induced by pressure overload (Oka et al. 2011). Most interestingly, CR was shown to induce nuclear localization of SIRT1 in a mechanism requiring eNOS, and this was associated with increased ischemic tolerance (Shinmura et al. 2008). SIRT1 and eNOS may comprise a mutually reinforcing activity loop, as for SIRT1 and AMPK.

With regard to other sirtuins, SIRT6 has been found to attenuate AKT signaling in the heart to protect against hypertrophy (Sundaresan et al. 2012). In this case, SIRT6 serves as a corepressor of IGF-activated genes by binding to the transcription factor c-jun. Finally, a new study shows that mice knocked out for one subunit of complex I in the heart show a buildup of $\mathrm{NADH}$, inactivation of SIRT3, and the hyperacetylation of cardiac mitochondrial proteins (Karamanlidis et al. 2013). These mice are much more susceptible to heart failure, reinforcing the established importance of SIRT3 in cardiac function (Pillai et al. 2010).

\section{Kidney}

Numerous studies have indicated protection of renal function by SIRT1, initiating with the report that SIRT2 mitigates oxidative stress in HK-2 cells (Hasegawa et al. 2008). In mice, SIRT1 genetic activation in transgenic mice or the application of STACs protects against various models of kidney injury (Funk et al. 2010; Hasegawa et al. 2010; He et al. 2010; Fan et al. 2013; Kim et al. 2013). SIRT1 also mitigates fibrosis following acute kidney injury by deacetylating Smad 4 and suppressing TGF- $\beta$ signaling (Simic et al. 2013). In addition, SIRT1 is required for CR-induced renal protection against hypoxia, in this case by deacetylating of FOXO3 and activating autophagy (Kume et al. 2010). Finally, CR is also renal-protective in a diabetes model in rats, and this is associated with activation of SIRT1 and deacetylation of NF-кB (Kitada et al. 2011).

A recent study points to a novel kind of communication between two different kidney compartments mediated by SIRT1. In one compartment, consisting of proximal tubule cells, SIRT1 determines the levels of the
NAD precursor nicotinamide mononucleotide (NMN) that are secreted. The secreted NMN then activates SIRT1 in a different kidney compartment, consisting of podocytes, to trigger stress resistance. The net effect of this circuit is the protection of the kidney and suppression of diabetic albuminuria (Hasegawa et al. 2013).

Opposite to these protective effects, SIRT1 may contribute to the pathophysiology of autosomal dominant polycystic kidney disease (ADPKD). This heritable disease, due to genetic defects in PKD1 or PKD2, affects up to one in 400 individuals and leads to kidney failure in the fourth to sixth decade of life. One recent study shows that up-regulation of SIRT1 by c-MYC occurs in a murine model of ADPKD (Zhou et al. 2013). Moreover, genetic or pharmacological inhibition of SIRT1 suppresses the growth of cysts in this model. SIRT1 may abet cyst formation by promoting cell survival mechanisms such as deacetylation and inhibition of p53. It is interesting and unusual that the activation of SIRT1 may be renalprotective in a normal setting, but the inhibition of SIRT1 may be efficacious in a disease setting.

\section{Endothelium and smooth muscle}

Many studies have revealed a deep connection between SIRT1 and the vasculature. Among the important substrates deacetylated by SIRT1 in endothelial cells (ECs) are eNOS (Mattagajasingh et al. 2007), LKB1 (Zu et al. 2010), Notch (Guarani et al. 2011), and p66shc (Zhou et al. 2011). The net effect of SIRT1 in ECs appears to be control of vessel growth (Potente et al. 2007) and protection against EC senescence (Ota et al. 2007) and, more generally, atherosclerosis. For example, sheer stress induces SIRT1, AMPK, eNOS, and mitochondrial biogenesis /Chen et al. 2010), and this is associated with phosphorylation and stabilization of SIRT1 by calmodulin-dependent protein kinase kinase (Wen et al. 2013). Inhibition of this SIRT1 induction sensitizes ECs to damage inflicted by oxidized LDL (Guo et al. 2013) and sensitizes apoE ${ }^{-/-}$mice to atherosclerosis (Zhang et al. 2008). The SIRT1/AMPK axis in ECs has been shown to be inducible by exercise or resveratrol in mice (Cacicedo et al. 2011; Takizawa et al. 2013).

In a second critical cell type of the vasculature, smooth muscle cells (SMCs), SIRT1 is also athero-protective, since selective depletion of this sirtuin from SMCs predisposes mice to atherosclerosis (Gorenne et al. 2013). In addition, SIRT1 restrains the induction of hypertrophy in SMCs by angiotensin II by reducing levels of its receptor (Li et al. 2011a). The effects of SIRT1 in ECs and SMCs may help explain the protective role of CR against atherosclerosis (Fontana et al. 2004) and (along with effects in other tissues) protection by this diet against cardiovascular disease in general.

\section{Discussion}

The interaction of diet and nutrient-sensing pathways plays an important role in regulating mammalian physiology and health. This review focused on the sirtuins and 
CR to revisit the original hypothesis that nutrient-sensing regulators mediate the effects of this diet on aging and diseases (Guarente 2000). The original proposal was based on the findings that sirtuins were $\mathrm{NAD}^{+}$-dependent protein deacetylases and known to counter aging in yeast. Now, years later, a large volume of data, particularly from mammals, begins to illustrate an elaborate set of physiological adaptations to caloric intake mediated by sirtuins. Studies that connect sirtuin activation with prevention of aging and diseases of aging in mouse models are many. It is also clear that other nutrient sensors, such as AMPK (Kahn et al. 2005), mTOR (Johnson et al. 2013), and FOXO (Kenyon, 2010), are very important in linking diet, metabolism, and aging. Indeed, numerous connections among all of these pathways are evident in the literature.

As far as medical intervention points, SIRT1 and mTORC1 appear to be candidate targets because small molecules have been described that can alter their activities (STACs and rapamycin, respectively). The idea that SIRT 1 could be activated by small molecules was initially resisted but now seems very likely based on an allosteric site in the protein (Hubbard et al. 2013). The challenge will be to tailor drugs to specific tissues; for example, creating brain-permeable compounds to treat Alzheimer's disease. In addition, it will be critical to learn whether activating compounds affect all SIRT1 substrates or only a subset, as suggested by recent biochemical studies. One might posit that small molecules that bind to the SIRT1 allosteric site mimic natural endogenous compounds that regulate the enzyme under certain physiological conditions; e.g., CR. If so, then the spectrum of effects elicited by the drugs might mimic the effects triggered by these physiological conditions and elicit a coordinated, protective response. Finally, supplementation with the NAD precursors NMN or nicotinamide riboside has been shown to counteract aging (Ramsey et al. 2008; Mouchiroud et al. 2013) and may offer another strategy of keying sirtuin surveillance to forestall aging and diseases.

\section{Acknowledgments}

I thank everyone who has contributed to the work highlighted in this essay. My laboratory is funded by grants from NIH and The Glenn Foundation for Medical Research.

\section{References}

Adler AS, Sinha S, Kawahara TL, Zhang JY, Segal E, Chang HY. 2007. Motif module map reveals enforcement of aging by continual NF-кB activity. Genes Dev 21: 3244-3257.

Albani D, Ateri E, Mazzuco S, Ghilardi A, Rodilossi S, Biella G, Ongaro F, Antuono P, Boldrini P, Di Giorgi E, et al. 2013. Modulation of human longevity by SIRT3 single nucleotide polymorphisms in the prospective study 'Treviso Longeva (TRELONG)'. Age (Dordr) doi: 10.1007/s11357-013-9559-2.

Alcendor RR, Gao S, Zhai P, Zablocki D, Holle E, Yu X, Tian B, Wagner T, Vatner SF, Sadoshima J. 2007. Sirt1 regulates aging and resistance to oxidative stress in the heart. Circ Res 100: 1512-1521.

Anderson RM, Bitterman KJ, Wood JG, Medvedik O, Sinclair DA. 2003. Nicotinamide and PNC1 govern lifespan exten- sion by calorie restriction in Saccharomyces cerevisiae. Nature 423: 181-185.

Asher G, Gatfield D, Stratmann M, Reinke H, Dibner C, Kreppel F, Mostoslavsky R, Alt FW, Schibler U. 2008. SIRT1 regulates circadian clock gene expression through PER2 deacetylation. Cell 134: 317-328.

Banerjee KK, Ayyub C, Ali SZ, Mandot V, Prasad NG, KolthurSeetharam U. 2012. dSir2 in the adult fat body, but not in muscles, regulates life span in a diet-dependent manner. Cell Rep 2: 1485-1491.

Banks AS, Kon N, Knight C, Matsumoto M, Gutierrez-Juarez R, Rossetti L, Gu W, Accili D. 2008. SirT1 gain of function increases energy efficiency and prevents diabetes in mice. Cell Metab 8: 333-341.

Barger JL, Kayo T, Vann JM, Arias EB, Wang J, Hacker TA, Wang Y, Raederstorff D, Morrow JD, Leeuwenburgh C, et al. 2008. A low dose of dietary resveratrol partially mimics caloric restriction and retards aging parameters in mice. PLOS ONE 3: e2264.

Bauer JH, Morris SN, Chang C, Flatt T, Wood JG, Helfand SL. 2009. dSir2 and Dmp53 interact to mediate aspects of CRdependent lifespan extension in D. melanogaster. Aging (Albany, NY Online) 1: 38-48.

Baur JA, Pearson KJ, Price NL, Jamieson HA, Lerin C, Kalra A, Prabhu VV, Allard JS, Lopez-Lluch G, Lewis K, et al. 2006. Resveratrol improves health and survival of mice on a highcalorie diet. Nature 444: 337-342.

Bell EL, Emerling BM, Ricoult SJ, Guarente L. 2011. SirT3 suppresses hypoxia inducible factor $1 \alpha$ and tumor growth by inhibiting mitochondrial ROS production. Oncogene 30: 2986-2996.

Berdichevsky A, Viswanathan M, Horvitz HR, Guarente L. 2006. C. elegans SIR-2.1 interacts with 14-3-3 proteins to activate DAF-16 and extend life span. Cell 125: 1165-1177.

Biason-Lauber A, Boni-Schnetzler M, Hubbard BP, Bouzakri K, Brunner A, Cavelti-Weder C, Keller C, Meyer-Boni M, Meier DT, Brorsson C, et al. 2013. Identification of a SIRT1 mutation in a family with type 1 diabetes. Cell Metab 17: 448-455.

Bishop NA, Guarente L. 2007. Two neurons mediate dietrestriction-induced longevity in C. elegans. Nature 447: 545549.

Boily G, Seifert EL, Bevilacqua L, He XH, Sabourin G, Estey C, Moffat C, Crawford S, Saliba S, Jardine K, et al. 2008. SirT1 regulates energy metabolism and response to caloric restriction in mice. PLoS One 3: e1759.

Bordone L, Motta MC, Picard F, Robinson A, Jhala US, Apfeld J, McDonagh T, Lemieux M, McBurney M, Szilvasi A, et al. 2006. Sirt 1 regulates insulin secretion by repressing UCP2 in pancreatic $\beta$ cells. PLOS Biol 4: e31.

Bordone L, Cohen D, Robinson A, Motta MC, van Veen E, Czopik A, Steele AD, Crowe H, Marmor S, Luo J, et al. 2007. SIRT1 transgenic mice show phenotypes resembling calorie restriction. Aging Cell 6: 759-767.

Brunet A, Sweeney LB, Sturgill JF, Chua KF, Greer PL, Lin Y, Tran H, Ross SE, Mostoslavsky R, Cohen HY, et al. 2004. Stress-dependent regulation of FOXO transcription factors by the SIRT1 deacetylase. Science 303: 2011-2015.

Burnett C, Valentini S, Cabreiro F, Goss M, Somogyvari M, Piper MD, Hoddinott M, Sutphin GL, Leko V, McElwee JJ, et al. 2011. Absence of effects of Sir2 overexpression on lifespan in C. elegans and Drosophila. Nature 477: 482485.

Cacicedo JM, Gauthier MS, Lebrasseur NK, Jasuja R, Ruderman NB, Ido Y. 2011. Acute exercise activates AMPK and eNOS in the mouse aorta. Am I Physiol Heart Circ Physiol 301: H1255-H1265. 
Cakir I, Perello M, Lansari O, Messier NJ, Vaslet CA, Nillni EA. 2009. Hypothalamic Sirt1 regulates food intake in a rodent model system. PLOS ONE 4: e8322.

Canto C, Gerhart-Hines Z, Feige JN, Lagouge M, Noriega L, Milne JC, Elliott PJ, Puigserver P, Auwerx J. 2009. AMPK regulates energy expenditure by modulating NAD+ metabolism and SIRT1 activity. Nature 458: 1056-1060.

Canto C, Jiang LQ, Deshmukh AS, Mataki C, Coste A, Lagouge M, Zierath JR, Auwerx J. 2010. Interdependence of AMPK and SIRT1 for metabolic adaptation to fasting and exercise in skeletal muscle. Cell Metab 11: 213-219.

Chalkiadaki A, Guarente L. 2012. High-fat diet triggers inflammation-induced cleavage of SIRT1 in adipose tissue to promote metabolic dysfunction. Cell Metab 16: 180-188.

Chang HC, Guarente L. 2013. SIRT1 mediates central circadian control in the SCN by a mechanism that decays with aging. Cell 153: 1448-1460.

Chen $\mathrm{D}$, Steele $\mathrm{AD}$, Lindquist S, Guarente L. 2005. Increase in activity during calorie restriction requires Sirt1. Science 310: 1641.

Chen D, Bruno J, Easlon E, Lin SJ, Cheng HL, Alt FW, Guarente L. 2008. Tissue-specific regulation of SIRT1 by calorie restriction. Genes Dev 22: 1753-1757.

Chen Z, Peng IC, Cui X, Li YS, Chien S, Shyy JY. 2010. Shear stress, SIRT1, and vascular homeostasis. Proc Natl Acad Sci 107: 10268-10273.

Civitarese AE, Carling S, Heilbronn LK, Hulver MH, Ukropcova B, Deutsch WA, Smith SR, Ravussin E. 2007. Calorie restriction increases muscle mitochondrial biogenesis in healthy humans. PLoS Med 4: e76.

Cohen HY, Miller C, Bitterman KJ, Wall NR, Hekking B, Kessler B, Howitz KT, Gorospe M, de Cabo R, Sinclair DA. 2004. Calorie restriction promotes mammalian cell survival by inducing the SIRT1 deacetylase. Science 305: 390-392.

Cohen DE, Supinski AM, Bonkowski MS, Donmez G, Guarente LP. 2009. Neuronal SIRT1 regulates endocrine and behavioral responses to calorie restriction. Genes Dev 23: 2812 2817.

Coppari R. 2012. Metabolic actions of hypothalamic SIRT1. Trends Endocrinol Metab 23: 179-185.

Costa Cdos S, Hammes TO, Rohden F, Margis R, Bortolotto JW, Padoin AV, Mottin CC, Guaragna RM. 2010. SIRT1 transcription is decreased in visceral adipose tissue of morbidly obese patients with severe hepatic steatosis. Obes Surg 20: 633-639.

Csibi A, Fendt SM, Li C, Poulogiannis G, Choo AY, Chapski DJ, Jeong SM, Dempsey JM, Parkhitko A, Morrison T, et al. 2013. The mTORC1 pathway stimulates glutamine metabolism and cell proliferation by repressing SIRT4. Cell 153: 840-854.

Dai H, Kustigian L, Carney D, Case A, Considine T, Hubbard BP, Perni RB, Riera TV, Szczepankiewicz B, Vlasuk GP, et al. 2010. SIRT1 activation by small molecules: Kinetic and biophysical evidence for direct interaction of enzyme and activator. J Biol Chem 285: 32695-32703.

Dietrich MO, Antunes C, Geliang G, Liu ZW, Borok E, Nie Y, Xu AW, Souza DO, Gao Q, Diano S, et al. 2010. Agrp neurons mediate Sirtl's action on the melanocortin system and energy balance: Roles for Sirt1 in neuronal firing and synaptic plasticity. I Neurosci 30: 11815-11825.

Dietrich MO, Bober J, Ferreira JG, Tellez LA, Mineur YS, Souza DO, Gao XB, Picciotto MR, Araujo I, Liu ZW, et al. 2012. AgRP neurons regulate development of dopamine neuronal plasticity and nonfood-associated behaviors. Nat Neurosci 15: 1108-1110.

Dominy JE Jr, Lee Y, Jedrychowski MP, Chim H, Jurczak MJ, Camporez JP, Ruan HB, Feldman J, Pierce K, Mostoslavsky R, et al. 2012. The deacetylase Sirt6 activates the acetyltransferase GCN5 and suppresses hepatic gluconeogenesis. Mol Cell 48: 900-913.

Donmez G, Wang D, Cohen DE, Guarente L. 2010. SIRT1 suppresses $\beta$-amyloid production by activating the $\alpha$-secretase gene ADAM10. Cell 142: 320-332.

Du J, Zhou Y, Su X, Yu JJ, Khan S, Jiang H, Kim J, Woo J, Kim JH, Choi $\mathrm{BH}$, et al. 2011. Sirt5 is a NAD-dependent protein lysine demalonylase and desuccinylase. Science 334: 806809.

Erion DM, Yonemitsu S, Nie Y, Nagai Y, Gillum MP, Hsiao JJ, Iwasaki T, Stark R, Weismann D, Yu XX, et al. 2009. SirT1 knockdown in liver decreases basal hepatic glucose production and increases hepatic insulin responsiveness in diabetic rats. Proc Natl Acad Sci 106: 11288-11293.

Fan H, Yang HC, You L, Wang YY, He WJ, Hao CM. 2013. The histone deacetylase, SIRT1, contributes to the resistance of young mice to ischemia/reperfusion-induced acute kidney injury. Kidney Int 83: 404-413.

Feige JN, Lagouge M, Canto C, Strehle A, Houten SM, Milne JC, Lambert PD, Mataki C, Elliott PJ, Auwerx J. 2008. Specific SIRT1 activation mimics low energy levels and protects against diet-induced metabolic disorders by enhancing fat oxidation. Cell Metab 8: 347-358.

Finley LW, Carracedo A, Lee J, Souza A, Egia A, Zhang J, TeruyaFeldstein J, Moreira PI, Cardoso SM, Clish CB, et al. 2011. SIRT3 opposes reprogramming of cancer cell metabolism through HIF1 $\alpha$ destabilization. Cancer Cell 19: 416-428.

Firestein R, Blander G, Michan S, Oberdoerffer P, Ogino S, Campbell J, Bhimavarapu A, Luikenhuis S, de Cabo R, Fuchs C, et al. 2008. The SIRT1 deacetylase suppresses intestinal tumorigenesis and colon cancer growth. PLOS ONE 3: e2020.

Fontana L, Meyer TE, Klein S, Holloszy JO. 2004. Long-term calorie restriction is highly effective in reducing the risk for atherosclerosis in humans. Proc Natl Acad Sci 101: 66596663.

Fulco M, Cen Y, Zhao P, Hoffman EP, McBurney MW, Sauve AA, Sartorelli V. 2008. Glucose restriction inhibits skeletal myoblast differentiation by activating SIRT1 through AMPKmediated regulation of Nampt. Dev Cell 14: 661-673.

Funk JA, Odejinmi S, Schnellmann RG. 2010. SRT1720 induces mitochondrial biogenesis and rescues mitochondrial function after oxidant injury in renal proximal tubule cells. J Pharmacol Exp Ther 333: 593-601.

Gao J, Wang WY, Mao YW, Graff J, Guan JS, Pan L, Mak G, Kim D, Su SC, Tsai LH. 2010. A novel pathway regulates memory and plasticity via SIRT1 and miR-134. Nature 466: 11051109.

Gao Z, Zhang J, Kheterpal I, Kennedy N, Davis RJ, Ye J. 2011. Sirtuin 1 (SIRT1) protein degradation in response to persistent c-Jun $\mathrm{N}$-terminal kinase 1 (JNK1) activation contributes to hepatic steatosis in obesity. I Biol Chem 286: 2222722234

Gerhart-Hines Z, Rodgers JT, Bare O, Lerin C, Kim SH, Mostoslavsky R, Alt FW, Wu Z, Puigserver P. 2007. Metabolic control of muscle mitochondrial function and fatty acid oxidation through SIRT1/PGC-1 $\alpha$. EMBO J 26: 1913-1923.

Giannakou ME, Goss M, Junger MA, Hafen E, Leevers SJ, Partridge L. 2004. Long-lived Drosophila with overexpressed dFOXO in adult fat body. Science 305: 361.

Gillum MP, Kotas ME, Erion DM, Kursawe R, Chatterjee P, Nead KT, Muise ES, Hsiao JJ, Frederick DW, Yonemitsu S, et al. 2011. SirT1 regulates adipose tissue inflammation. Diabetes 60: 3235-3245.

Gorenne I, Kumar S, Gray K, Figg N, Yu H, Mercer J, Bennett M. 2013. Vascular smooth muscle cell sirtuin 1 protects against 
DNA damage and inhibits atherosclerosis. Circulation 127: 386-396.

Guarani V, Deflorian G, Franco CA, Kruger M, Phng LK, Bentley K, Toussaint L, Dequiedt F, Mostoslavsky R, Schmidt MH, et al. 2011. Acetylation-dependent regulation of endothelial Notch signalling by the SIRT1 deacetylase. Nature 473: 234238.

Guarente L. 2000. Sir2 links chromatin silencing, metabolism, and aging. Genes Dev 14: 1021-1026.

Guarente L. 2011. Sirtuins, aging, and medicine. N Engl J Med 364: 2235-2244.

Guo H, Chen Y, Liao L, Wu W. 2013. Resveratrol protects HUVECs from oxidized-LDL induced oxidative damage by autophagy upregulation via the AMPK/SIRT1 pathway. Cardiovasc Drugs Ther 27: 189-198.

Haigis MC, Mostoslavsky R, Haigis KM, Fahie K, Christodoulou DC, Murphy AJ, Valenzuela DM, Yancopoulos GD, Karow M, Blander G, et al. 2006. SIRT4 inhibits glutamate dehydrogenase and opposes the effects of calorie restriction in pancreatic $\beta$ cells. Cell 126: 941-954.

Hallows WC, Lee S, Denu JM. 2006. Sirtuins deacetylate and activate mammalian acetyl-CoA synthetases. Proc Natl Acad Sci 103: 10230-10235.

Hallows WC, Yu W, Smith BC, Devries MK, Ellinger JJ, Someya S, Shortreed MR, Prolla T, Markley JL, Smith LM, et al. 2011. Sirt3 promotes the urea cycle and fatty acid oxidation during dietary restriction. Mol Cell 41: 139-149.

Hallows WC, Yu W, Denu JM. 2012. Regulation of glycolytic enzyme phosphoglycerate mutase-1 by Sirt1 protein-mediated deacetylation. J Biol Chem 287: 3850-3858.

Hariharan N, Maejima Y, Nakae J, Paik J, Depinho RA, Sadoshima J. 2010. Deacetylation of FoxO by Sirtl plays an essential role in mediating starvation-induced autophagy in cardiac myocytes. Circ Res 107: 1470-1482.

Hasegawa K, Wakino S, Yoshioka K, Tatematsu S, Hara Y, Minakuchi H, Washida N, Tokuyama H, Hayashi K, Itoh H. 2008. Sirt 1 protects against oxidative stress-induced renal tubular cell apoptosis by the bidirectional regulation of catalase expression. Biochem Biophys Res Commun 372: 51-56.

Hasegawa K, Wakino S, Yoshioka K, Tatematsu S, Hara Y, Minakuchi H, Sueyasu K, Washida N, Tokuyama H, Tzukerman M, et al. 2010. Kidney-specific overexpression of Sirtl protects against acute kidney injury by retaining peroxisome function. J Biol Chem 285: 13045-13056.

Hasegawa K, Wakino S, Simic P, Sakamaki Y, Minakuchi H, Fujimura K, Hosoya K, Komatsu M, Kaneko Y, Kanda T, et al. 2013. Renal tubular Sirt1 attenuates diabetic albuminuria by epigenetically suppressing Claudin-1 overexpression in podocytes. Nat Med (in press).

He W, Wang Y, Zhang MZ, You L, Davis LS, Fan H, Yang HC, Fogo AB, Zent R, Harris RC, et al. 2010. Sirtl activation protects the mouse renal medulla from oxidative injury. $I$ Clin Invest 120: 1056-1068.

Herranz D, Munoz-Martin M, Canamero M, Mulero F, MartinezPastor B, Fernandez-Capetillo O, Serrano M. 2010. Sirt1 improves healthy ageing and protects from metabolic syndrome-associated cancer. Nat Commun 1: 3 .

Herskovits AZ, Guarente L. 2013. Sirtuin deacetylases in neurodegenerative diseases of aging. Cell Res 23: 746-758.

Hirschey MD, Shimazu T, Goetzman E, Jing E, Schwer B, Lombard DB, Grueter CA, Harris C, Biddinger S, Ilkayeva OR, et al. 2010. SIRT3 regulates mitochondrial fatty-acid oxidation by reversible enzyme deacetylation. Nature 464: 121-125.

Hirschey MD, Shimazu T, Jing E, Grueter CA, Collins AM, Aouizerat B, Stancakova A, Goetzman E, Lam MM, Schwer
B, et al. 2011. SIRT3 deficiency and mitochondrial protein hyperacetylation accelerate the development of the metabolic syndrome. Mol Cell 44: 177-190.

Hoffmann J, Romey R, Fink C, Yong L, Roeder T. 2013. Overexpression of Sir2 in the adult fat body is sufficient to extend lifespan of male and female Drosophila. Aging (Albany, NY Online) 5: 315-327.

Hou X, Xu S, Maitland-Toolan KA, Sato K, Jiang B, Ido Y, Lan F, Walsh K, Wierzbicki M, Verbeuren TJ, et al. 2008. SIRT1 regulates hepatocyte lipid metabolism through activating AMP-activated protein kinase. I Biol Chem 283: 2001520026.

Howitz KT, Bitterman KJ, Cohen HY, Lamming DW, Lavu S, Wood JG, Zipkin RE, Chung P, Kisielewski A, Zhang LL, et al. 2003. Small molecule activators of sirtuins extend Saccharomyces cerevisiae lifespan. Nature 425: 191-196.

Hsu CP, Zhai P, Yamamoto T, Maejima Y, Matsushima S, Hariharan N, Shao D, Takagi H, Oka S, Sadoshima J. 2010. Silent information regulator 1 protects the heart from ischemia/reperfusion. Circulation 122: 2170-2182.

Hubbard BP, Gomes AP, Dai H, Li J, Case AW, Considine T, Riera TV, Lee JE, E SY, Lamming DW, et al. 2013. Evidence for a common mechanism of SIRT1 regulation by allosteric activators. Science 339: 1216-1219.

Hwangbo DS, Gershman B, Tu MP, Palmer M, Tatar M. 2004. Drosophila dFOXO controls lifespan and regulates insulin signalling in brain and fat body. Nature 429: 562-566.

Imai S, Armstrong CM, Kaeberlein M, Guarente L. 2000. Transcriptional silencing and longevity protein Sir2 is an NAD-dependent histone deacetylase. Nature 403: 795-800.

Iwabu M, Yamauchi T, Okada-Iwabu M, Sato K, Nakagawa T, Funata M, Yamaguchi M, Namiki S, Nakayama R, Tabata $M$, et al. 2010. Adiponectin and AdipoR1 regulate PGC-1 $\alpha$ and mitochondria by $\mathrm{Ca}^{2+}$ and AMPK/SIRT1. Nature 464: 13131319.

Jeong H, Cohen DE, Cui L, Supinski A, Savas JN, Mazzulli JR, Yates JR 3rd, Bordone L, Guarente L, Krainc D. 2011. Sirt1 mediates neuroprotection from mutant huntingtin by activation of the TORC1 and CREB transcriptional pathway. Nat Med 18: 159-165.

Jeong SM, Xiao C, Finley LW, Lahusen T, Souza AL, Pierce K, Li YH, Wang X, Laurent G, German NJ, et al. 2013. SIRT4 has tumor-suppressive activity and regulates the cellular metabolic response to DNA damage by inhibiting mitochondrial glutamine metabolism. Cancer Cell 23: 450-463.

Jiang M, Wang J, Fu J, Du L, Jeong H, West T, Xiang L, Peng Q, Hou Z, Cai H, et al. 2011. Neuroprotective role of Sirtl in mammalian models of Huntington's disease through activation of multiple Sirt1 targets. Nat Med 18: 153-158.

Jing E, Gesta S, Kahn CR. 2007. SIRT2 regulates adipocyte differentiation through FoxO1 acetylation/deacetylation. Cell Metab 6: 105-114.

Johnson SM, Rabinovitch PS, Kaeberlein M. 2013. mTOR is a key modulator of aging and age-related disease. Nature 493: 338-345.

Kaeberlein M, McVey M, Guarente L. 1999. The SIR2/3/4 complex and SIR2 alone promote longevity in Saccharomyces cerevisiae by two different mechanisms. Genes Dev 13: 2570-2580.

Kaeberlein M, Kirkland KT, Fields S, Kennedy BK. 2004. Sir2independent life span extension by calorie restriction in yeast. PLoS Biol 2: E296.

Kaeberlein M, McDonagh T, Heltweg B, Hixon J, Westman EA, Caldwell SD, Napper A, Curtis R, DiStefano PS, Fields S, et al. 2005. Substrate-specific activation of sirtuins by resveratrol. I Biol Chem 280: 17038-17045. 
Kahn BB, Alquier T, Carling D, Hardie DG. 2005. AMPactivated protein kinase: Ancient energy gauge provides clues to modern understanding of metabolism. Cell Metab 1: $15-25$

Kanfi Y, Naiman S, Amir G, Peshti V, Zinman G, Nahum L, BarJoseph Z, Cohen HY. 2012. The sirtuin SIRT6 regulates lifespan in male mice. Nature 483: 218-221.

Karamanlidis G, Lee CF, Garcia-Menendez L, Kolwicz SC Jr, Suthammarak W, Gong G, Sedensky MM, Morgan PG, Wang W, Tian R. 2013. Mitochondrial complex I deficiency increases protein acetylation and accelerates heart failure. Cell Metab 18: 239-250.

Kawahara TL, Michishita E, Adler AS, Damian M, Berber E, Lin M, McCord RA, Ongaigui KC, Boxer LD, Chang HY, et al. 2009. SIRT6 links histone H3 lysine 9 deacetylation to NF-кB-dependent gene expression and organismal life span. Cell 136: 62-74.

Kemper JK, Xiao Z, Ponugoti B, Miao J, Fang S, Kanamaluru D, Tsang S, Wu SY, Chiang CM, Veenstra TD. 2009. FXR acetylation is normally dynamically regulated by p300 and SIRT1 but constitutively elevated in metabolic disease states. Cell Metab 10: 392-404.

Kenyon CJ. 2010. The genetics of aging. Nature 464: 504-512.

Kim D, Nguyen MD, Dobbin MM, Fischer A, Sananbenesi F, Rodgers JT, Delalle I, Baur JA, Sui G, Armour SM, et al. 2007. SIRT1 deacetylase protects against neurodegeneration in models for Alzheimer's disease and amyotrophic lateral sclerosis. EMBO J 26: 3169-3179.

Kim HS, Xiao C, Wang RH, Lahusen T, Xu X, Vassilopoulos A, Vazquez-Ortiz G, Jeong WI, Park O, Ki SH, et al. 2010. Hepatic-specific disruption of SIRT6 in mice results in fatty liver formation due to enhanced glycolysis and triglyceride synthesis. Cell Metab 12: 224-236.

Kim MY, Lim JH, Youn HH, Hong YA, Yang KS, Park HS, Chung S, Ko SH, Shin SJ, Choi BS, et al. 2013. Resveratrol prevents renal lipotoxicity and inhibits mesangial cell glucotoxicity in a manner dependent on the AMPK-SIRT1-PGC1 $\alpha$ axis in $\mathrm{db} / \mathrm{db}$ mice. Diabetologia 56: 204-217.

Kitada M, Takeda A, Nagai T, Ito H, Kanasaki K, Koya D. 2011. Dietary restriction ameliorates diabetic nephropathy through anti-inflammatory effects and regulation of the autophagy via restoration of Sirtl in diabetic Wistar fatty $(\mathrm{fa} / \mathrm{fa})$ rats: A model of type 2 diabetes. Exp Diabetes Res 2011: 908185.

Knight CM, Gutierrez-Juarez R, Lam TK, Arrieta-Cruz I, Huang L, Schwartz G, Barzilai N, Rossetti L. 2011. Mediobasal hypothalamic SIRT1 is essential for resveratrol's effects on insulin action in rats. Diabetes 60: 2691-2700.

Koltai E, Szabo Z, Atalay M, Boldogh I, Naito H, Goto S, Nyakas C, Radak Z. 2010. Exercise alters SIRT1, SIRT6, NAD and NAMPT levels in skeletal muscle of aged rats. Mech Ageing Dev 131: 21-28.

Kume S, Uzu T, Horiike K, Chin-Kanasaki M, Isshiki K, Araki S, Sugimoto T, Haneda M, Kashiwagi A, Koya D. 2010. Calorie restriction enhances cell adaptation to hypoxia through Sirt1-dependent mitochondrial autophagy in mouse aged kidney. J Clin Invest 120: 1043-1055.

Lagouge M, Argmann C, Gerhart-Hines Z, Meziane H, Lerin C, Daussin F, Messadeq N, Milne J, Lambert P, Elliott P, et al. 2006. Resveratrol improves mitochondrial function and protects against metabolic disease by activating SIRT1 and PGC-1 $\alpha$. Cell 127: 1109-1122.

Lam YY, Peterson CM, Ravussin E. 2013. Resveratrol vs. calorie restriction: Data from rodents to humans. Exp Gerontol 48: $1018-1024$.

Lamming DW, Latorre-Esteves M, Medvedik O, Wong SN, Tsang FA, Wang C, Lin SJ, Sinclair DA. 2005. HST2 mediates
SIR2-independent life-span extension by calorie restriction. Science 309: 1861-1864.

Lan F, Cacicedo JM, Ruderman N, Ido Y. 2008. SIRT1 modulation of the acetylation status, cytosolic localization, and activity of LKB1. Possible role in AMP-activated protein kinase activation. I Biol Chem 283: 27628-27635.

Laurent G, German NJ, Saha AK, de Boer VC, Davies M, Koves TR, Dephoure N, Fischer F, Boanca G, Vaitheesvaran B, et al. 2013. SIRT4 coordinates the balance between lipid synthesis and catabolism by repressing malonyl CoA decarboxylase. Mol Cell 50: 686-698.

Li X, Zhang S, Blander G, Tse JG, Krieger M, Guarente L. 2007. SIRT1 deacetylates and positively regulates the nuclear receptor LXR. Mol Cell 28: 91-106.

Li L, Gao P, Zhang H, Chen H, Zheng W, Lv X, Xu T, Wei Y, Liu D, Liang C. 2011a. SIRT1 inhibits angiotensin II-induced vascular smooth muscle cell hypertrophy. Acta Biochim Biophys Sin (Shanghai) 43: 103-109.

Li Y, Xu S, Giles A, Nakamura K, Lee JW, Hou X, Donmez G, Li J, Luo Z, Walsh K, et al. 2011b. Hepatic overexpression of SIRT1 in mice attenuates endoplasmic reticulum stress and insulin resistance in the liver. FASEB J 25: 1664-1679.

Li HJ, Che XM, Zhao W, He SC, Zhang ZL, Chen R, Fan L, Jia ZL. 2013. Diet-induced obesity promotes murine gastric cancer growth through a nampt/sirt1/c-myc positive feedback loop. Oncol Rep doi: 10.3892/or.2013.2678.

Libert S, Bonkowski MS, Pointer K, Pletcher SD, Guarente L. 2012. Deviation of innate circadian period from $24 \mathrm{~h}$ reduces longevity in mice. Aging Cell 11: 794-800.

Lim JH, Lee YM, Chun YS, Chen J, Kim JE, Park JW. 2010. Sirtuin 1 modulates cellular responses to hypoxia by deacetylating hypoxia-inducible factor $1 \alpha$. Mol Cell 38: $864-$ 878.

Lin SJ, Defossez PA, Guarente L. 2000. Requirement of NAD and SIR2 for life-span extension by calorie restriction in Saccharomyces cerevisiae. Science 289: 2126-2128.

Lin SJ, Kaeberlein M, Andalis AA, Sturtz LA, Defossez PA, Culotta VC, Fink GR, Guarente L. 2002. Calorie restriction extends Saccharomyces cerevisiae lifespan by increasing respiration. Nature 418: 344-348.

Liu Y, Dentin R, Chen D, Hedrick S, Ravnskjaer K, Schenk S, Milne J, Meyers DJ, Cole P, Yates J 3rd, et al. 2008. A fasting inducible switch modulates gluconeogenesis via activator/ coactivator exchange. Nature 456: 269-273.

Lombard DB, Alt FW, Cheng HL, Bunkenborg J, Streeper RS, Mostoslavsky R, Kim J, Yancopoulos G, Valenzuela D, Murphy A, et al. 2007. Mammalian Sir2 homolog SIRT3 regulates global mitochondrial lysine acetylation. Mol Cell Biol 27: 8807-8814.

Ludewig AH, Izrayelit Y, Park D, Malik RU, Zimmermann A, Mahanti P, Fox BW, Bethke A, Doering F, Riddle DL, et al. 2013. Pheromone sensing regulates Caenorhabditis elegans lifespan and stress resistance via the deacetylase SIR-2.1. Proc Natl Acad Sci 110: 5522-5527.

Mattagajasingh I, Kim CS, Naqvi A, Yamamori T, Hoffman TA, Jung SB, DeRicco J, Kasuno K, Irani K. 2007. Sirt1 promotes endothelium-dependent vascular relaxation by activating endothelial nitric oxide synthase. Proc Natl Acad Sci 104: 14855-14860.

McCay CM, Crowell MF, Maynard LA. 1935. The effect of retarded growth upon the length of the life span and upon the ultimate body size. J Nutr 10: 63-73.

Mercken EM, Hu J, Krzysik-Walker S, Wei M, Li Y, McBurney MW, Cabo RD, Longo VD. 2013. SIRT1 but not its increased expression is essential for lifespan extension in caloric restricted mice. Aging Cell doi: 10.1111/acel.12151. 
Michan S, Li Y, Chou MM, Parrella E, Ge H, Long JM, Allard JS, Lewis K, Miller M, Xu W, et al. 2010. SIRT1 is essential for normal cognitive function and synaptic plasticity. I Neurosci 30: 9695-9707.

Milne JC, Lambert PD, Schenk S, Carney DP, Smith JJ, Gagne DJ, Jin L, Boss O, Perni RB, Vu CB, et al. 2007. Small molecule activators of SIRT1 as therapeutics for the treatment of type 2 diabetes. Nature 450: 712-716.

Min SW, Cho SH, Zhou Y, Schroeder S, Haroutunian V, Seeley WW, Huang EJ, Shen Y, Masliah E, Mukherjee C, et al. 2010. Acetylation of $\tau$ inhibits its degradation and contributes to tauopathy. Neuron 67: 953-966.

Motta MC, Divecha N, Lemieux M, Kamel C, Chen D, Gu W, Bultsma Y, McBurney M, Guarente L. 2004. Mammalian SIRT1 represses forkhead transcription factors. Cell 116: 551-563.

Mouchiroud L, Houtkooper RH, Moullan N, Katsyuba E, Ryu D, Canto C, Mottis A, Jo YS, Viswanathan M, Schoonjans K, et al. 2013. The $\mathrm{NAD}(+) /$ sirtuin pathway modulates longevity through activation of mitochondrial UPR and FOXO signaling. Cell 154: 430-441.

Moynihan KA, Grimm AA, Plueger MM, Bernal-Mizrachi E, Ford E, Cras-Meneur C, Permutt MA, Imai S. 2005. Increased dosage of mammalian Sir2 in pancreatic $\beta$ cells enhances glucose-stimulated insulin secretion in mice. Cell Metab 2: 105-117.

Nakagawa T, Lomb DI, Haigis MC, Guarente L. 2009. SIRT5 Deacetylates carbamoyl phosphate synthetase 1 and regulates the urea cycle. Cell 137: 560-570.

Nakahata Y, Kaluzova M, Grimaldi B, Sahar S, Hirayama J, Chen D, Guarente LP, Sassone-Corsi P. 2008. The NAD+dependent deacetylase SIRT1 modulates CLOCK-mediated chromatin remodeling and circadian control. Cell 134: 329340.

Nakahata Y, Sahar S, Astarita G, Kaluzova M, Sassone-Corsi P. 2009. Circadian control of the NAD+ salvage pathway by CLOCK-SIRT1. Science 324: 654-657.

Narasimhan SD, Yen K, Tissenbaum HA. 2009. Converging pathways in lifespan regulation. Curr Biol 19: R657-R666.

Nasrin N, Wu X, Fortier E, Feng Y, Bare OC, Chen S, Ren X, Wu Z, Streeper RS, Bordone L. 2010. SIRT4 regulates fatty acid oxidation and mitochondrial gene expression in liver and muscle cells. J Biol Chem 285: 31995-32002.

Nisoli E, Tonello C, Cardile A, Cozzi V, Bracale R, Tedesco L, Falcone S, Valerio A, Cantoni O, Clementi E, et al. 2005. Calorie restriction promotes mitochondrial biogenesis by inducing the expression of eNOS. Science 310: 314-317.

Noriega LG, Feige JN, Canto C, Yamamoto H, Yu J, Herman MA, Mataki C, Kahn BB, Auwerx J. 2011. CREB and ChREBP oppositely regulate SIRT1 expression in response to energy availability. EMBO Rep 12: 1069-1076.

Oka S, Alcendor R, Zhai P, Park JY, Shao D, Cho J, Yamamoto T, Tian B, Sadoshima J. 2011. PPAR $\alpha-S i r t 1$ complex mediates cardiac hypertrophy and failure through suppression of the ERR transcriptional pathway. Cell Metab 14: 598-611.

Ota H, Akishita M, Eto M, Iijima K, Kaneki M, Ouchi Y. 2007. Sirt1 modulates premature senescence-like phenotype in human endothelial cells. J Mol Cell Cardiol 43: 571-579.

Park SJ, Ahmad F, Philp A, Baar K, Williams T, Luo H, Ke H, Rehmann H, Taussig R, Brown AL, et al. 2012. Resveratrol ameliorates aging-related metabolic phenotypes by inhibiting cAMP phosphodiesterases. Cell 148: 421-433.

Pedersen SB, Olholm J, Paulsen SK, Bennetzen MF, Richelsen B. 2008. Low Sirt1 expression, which is upregulated by fasting, in human adipose tissue from obese women. Int $I$ Obes (Lond) 32: 1250-1255.
Peng C, Lu Z, Xie Z, Cheng Z, Chen Y, Tan M, Luo H, Zhang Y, He W, Yang K, et al. 2011. The first identification of lysine malonylation substrates and its regulatory enzyme. Mol Cell Proteomics 10: M111.012658.

Pfluger PT, Herranz D, Velasco-Miguel S, Serrano M, Tschop MH. 2008. Sirt1 protects against high-fat diet-induced metabolic damage. Proc Natl Acad Sci 105: 9793-9798.

Picard F, Kurtev M, Chung N, Topark-Ngarm A, Senawong T, Machado De Oliveira R, Leid M, McBurney MW, Guarente L. 2004. Sirt 1 promotes fat mobilization in white adipocytes by repressing PPAR $\gamma$. Nature 429: 771-776.

Pillai VB, Sundaresan NR, Jeevanandam V, Gupta MP. 2010. Mitochondrial SIRT3 and heart disease. Cardiovasc Res 88: 250-256.

Pittendrigh CS, Minis DH. 1972. Circadian systems: Longevity as a function of circadian resonance in Drosophila melanogaster. Proc Natl Acad Sci 69: 1537-1539.

Planavila A, Iglesias R, Giralt M, Villarroya F. 2011. Sirt1 acts in association with PPAR $\alpha$ to protect the heart from hypertrophy, metabolic dysregulation, and inflammation. Cardiovasc Res 90: 276-284.

Ponugoti B, Kim DH, Xiao Z, Smith Z, Miao J, Zang M, Wu SY, Chiang CM, Veenstra TD, Kemper JK. 2010. SIRT1 deacetylates and inhibits SREBP-1C activity in regulation of hepatic lipid metabolism. J Biol Chem 285: 33959-33970.

Porteiro B, Diaz-Ruiz A, Martinez G, Senra A, Vidal A, Serrano M, Gualillo O, Lopez M, Malagon MM, Dieguez C, et al. 2013. Ghrelin requires p53 to stimulate lipid storage in fat and liver. Endocrinology doi: 10.1210/en.2013-1176.

Potente M, Ghaeni L, Baldessari D, Mostoslavsky R, Rossig L, Dequiedt F, Haendeler J, Mione M, Dejana E, Alt FW, et al. 2007. SIRT1 controls endothelial angiogenic functions during vascular growth. Genes Dev 21: 2644-2658.

Price NL, Gomes AP, Ling AJ, Duarte FV, Martin-Montalvo A, North BJ, Agarwal B, Ye L, Ramadori G, Teodoro JS, et al. 2012. SIRT1 is required for AMPK activation and the beneficial effects of resveratrol on mitochondrial function. Cell Metab 15: 675-690.

Purushotham A, Schug TT, Xu Q, Surapureddi S, Guo X, Li X. 2009. Hepatocyte-specific deletion of SIRT1 alters fatty acid metabolism and results in hepatic steatosis and inflammation. Cell Metab 9: 327-338.

Qiang L, Wang L, Kon N, Zhao W, Lee S, Zhang Y, Rosenbaum M, Zhao Y, Gu W, Farmer SR, et al. 2012. Brown remodeling of white adipose tissue by SirT1-dependent deacetylation of Ppary. Cell 150: 620-632.

Qiu X, Brown K, Hirschey MD, Verdin E, Chen D. 2010. Calorie restriction reduces oxidative stress by SIRT3-mediated SOD2 activation. Cell Metab 12: 662-667.

Ramadori G, Lee CE, Bookout AL, Lee S, Williams KW, Anderson J, Elmquist JK, Coppari R. 2008. Brain SIRT1: Anatomical distribution and regulation by energy availability. J Neurosci 28: 9989-9996.

Ramadori G, Fujikawa T, Fukuda M, Anderson J, Morgan DA, Mostoslavsky R, Stuart RC, Perello M, Vianna CR, Nillni EA, et al. 2010. SIRT1 deacetylase in POMC neurons is required for homeostatic defenses against diet-induced obesity. Cell Metab 12: 78-87.

Ramsey KM, Mills KF, Satoh A, Imai S. 2008. Age-associated loss of Sirt1-mediated enhancement of glucose-stimulated insulin secretion in $\beta$ cell-specific Sirt1-overexpressing (BESTO) mice. Aging Cell 7: 78-88.

Ramsey KM, Yoshino J, Brace CS, Abrassart D, Kobayashi Y, Marcheva B, Hong HK, Chong JL, Buhr ED, Lee C, et al. 2009. Circadian clock feedback cycle through NAMPT-mediated NAD+ biosynthesis. Science 324: 651-654. 
Rizki G, Iwata TN, Li J, Riedel CG, Picard CL, Jan M, Murphy CT, Lee SS. 2011. The evolutionarily conserved longevity determinants HCF-1 and SIR-2.1/SIRT1 collaborate to regulate DAF-16/FOXO. PLoS Genet 7: e1002235.

Rodgers JT, Lerin C, Haas W, Gygi SP, Spiegelman BM, Puigserver P. 2005. Nutrient control of glucose homeostasis through a complex of PGC-1 $\alpha$ and SIRT1. Nature 434: 113-118.

Rogina B, Helfand SL. 2004. Sir2 mediates longevity in the fly through a pathway related to calorie restriction. Proc Natl Acad Sci 101: 15998-16003.

Rothgiesser KM, Erener S, Waibel S, Luscher B, Hottiger MO. 2010. SIRT2 regulates NF-кB dependent gene expression through deacetylation of p65 Lys310. J Cell Sci 123: 42514258.

Sasaki T, Kim HJ, Kobayashi M, Kitamura YI, Yokota-Hashimoto H, Shiuchi T, Minokoshi Y, Kitamura T. 2010. Induction of hypothalamic Sirt1 leads to cessation of feeding via agoutirelated peptide. Endocrinology 151: 2556-2566.

Satoh A, Brace CS, Ben-Josef G, West T, Wozniak DF, Holtzman DM, Herzog ED, Imai S. 2010. SIRT1 promotes the central adaptive response to diet restriction through activation of the dorsomedial and lateral nuclei of the hypothalamus. I Neurosci 30: 10220-10232.

Satoh A, Brace CS, Rensing N, Clifton P, Wozniak DF, Herzog ED, Yamada KA, Imai SI. 2013. Sirtl extends life span and delays aging in mice through the regulation of Nk2 homeobox 1 in the DMH and LH. Cell Metab 18: 416-430.

Schenk S, McCurdy CE, Philp A, Chen MZ, Holliday MJ, Bandyopadhyay GK, Osborn O, Baar K, Olefsky JM. 2011. Sirt 1 enhances skeletal muscle insulin sensitivity in mice during caloric restriction. J Clin Invest 121: 4281-4288.

Schwer B, Bunkenborg J, Verdin RO, Andersen JS, Verdin E. 2006. Reversible lysine acetylation controls the activity of the mitochondrial enzyme acetyl-CoA synthetase 2. Proc Natl Acad Sci 103: 10224-10229.

Schmeisser K, Mansfeld J, Kuhlow D, Weimer S, Priebe S, Heiland I, Birringer M, Groth M, Segref A, Kanfi Y, et al. 2013. Role of sirtuins in lifespan regulation is linked to methylation of nicotinamide. Nat Chem Biol (in press).

Sebastian C, Zwaans BM, Silberman DM, Gymrek M, Goren A, Zhong L, Ram O, Truelove J, Guimaraes AR, Toiber D, et al. 2012. The histone deacetylase SIRT6 is a tumor suppressor that controls metabolism. Cell 15: 1185-1199.

Shinmura K, Tamaki K, Bolli R. 2008. Impact of 6-mo caloric restriction on myocardial ischemic tolerance: Possible involvement of nitric oxide-dependent increase in nuclear Sirt1. Am J Physiol Heart Circ Physiol 295: H2348H2355.

Simic P, Williams EO, Bell EL, Gong JJ, Bonkowski M, Guarente L. 2013. SIRT1 suppresses the epithelial-to-mesenchymal transition in cancer metastasis and organ fibrosis. Cell Rep 3: 1175-1186.

Someya S, Yu W, Hallows WC, Xu J, Vann JM, Leeuwenburgh C, Tanokura M, Denu JM, Prolla TA. 2010. Sirt3 mediates reduction of oxidative damage and prevention of age-related hearing loss under caloric restriction. Cell 143: 802-812.

Speakman JR, Mitchell SE. 2011. Caloric restriction. Mol Aspects Med 32: 159-221.

Stumpferl SW, Brand SE, Jiang JC, Korona B, Tiwari A, Dai J, Seo JG, Jazwinski SM. 2012. Natural genetic variation in yeast longevity. Genome Res 22: 1963-1973.

Sundaresan NR, Vasudevan P, Zhong L, Kim G, Samant S, Parekh V, Pillai VB, Ravindra PV, Gupta M, Jeevanandam V, et al. 2012. The sirtuin SIRT6 blocks IGF-Akt signaling and development of cardiac hypertrophy by targeting c-Jun. Nat Med 18: 1643-1650.
Takizawa $\mathrm{Y}$, Kosuge $\mathrm{Y}$, Awaji H, Tamura E, Takai A, Yanai T, Yamamoto R, Kokame K, Miyata T, Nakata R, et al. 2013. Up-regulation of endothelial nitric oxide synthase (eNOS), silent mating type information regulation 2 homologue 1 (SIRT1) and autophagy-related genes by repeated treatments with resveratrol in human umbilical vein endothelial cells. Br J Nutr doi: 10.1017/S0007114513001670.

Tanno M, Kuno A, Yano T, Miura T, Hisahara S, Ishikawa S, Shimamoto K, Horio Y. 2010. Induction of manganese superoxide dismutase by nuclear translocation and activation of SIRT1 promotes cell survival in chronic heart failure. I Biol Chem 285: 8375-8382.

Tao R, Coleman MC, Pennington JD, Ozden O, Park SH, Jiang H, Kim HS, Flynn CR, Hill S, Hayes McDonald W, et al. 2010. Sirt3-mediated deacetylation of evolutionarily conserved lysine 122 regulates MnSOD activity in response to stress. Mol Cell 40: 893-904.

Tissenbaum HA, Guarente L. 2001. Increased dosage of a sir-2 gene extends lifespan in Caenorhabditis elegans. Nature 410: $227-230$.

Valentinuzzi VS, Scarbrough K, Takahashi JS, Turek FW. 1997. Effects of aging on the circadian rhythm of wheel-running activity in C57BL/6 mice. Am I Physiol 273: R1957R1964.

Velasquez DA, Martinez G, Romero A, Vazquez MJ, Boit KD, Dopeso-Reyes IG, Lopez M, Vidal A, Nogueiras R, Dieguez C. 2011. The central Sirtuin 1/p53 pathway is essential for the orexigenic action of ghrelin. Diabetes 60: 1177-1185.

Viswanathan M, Guarente L. 2011. Regulation of Caenorhabditis elegans lifespan by sir-2.1 transgenes. Nature 477: E1-E2.

Viswanathan M, Kim SK, Berdichevsky A, Guarente L. 2005. A role for SIR-2.1 regulation of ER stress response genes in determining C. elegans life span. Dev Cell 5: 605-615.

Walker AK, Yang F, Jiang K, Ji JY, Watts JL, Purushotham A, Boss O, Hirsch ML, Ribich S, Smith JJ, et al. 2010. Conserved role of SIRT1 orthologs in fasting-dependent inhibition of the lipid/cholesterol regulator SREBP. Genes Dev 24: 1403-1417.

Wang H, Qiang L, Farmer SR. 2008. Identification of a domain within peroxisome proliferator-activated receptor $\gamma$ regulating expression of a group of genes containing fibroblast growth factor 21 that are selectively repressed by SIRT1 in adipocytes. Mol Cell Biol 28: 188-200.

Wang RH, Li C, Deng CX. 2010. Liver steatosis and increased ChREBP expression in mice carrying a liver specific SIRT1 null mutation under a normal feeding condition. Int I Biol Sci 6: 682-690.

Wang RH, Kim HS, Xiao C, Xu X, Gavrilova O, Deng CX. 2011. Hepatic Sirt1 deficiency in mice impairs mTorc2/Akt signaling and results in hyperglycemia, oxidative damage, and insulin resistance. J Clin Invest 121: 4477-4490.

Wen L, Chen Z, Zhang F, Cui X, Sun W, Geary GG, Wang Y, Johnson DA, Zhu Y, Chien S, et al. 2013. Ca2+/calmodulindependent protein kinase kinase $\beta$ phosphorylation of Sirtuin 1 in endothelium is atheroprotective. Proc Natl Acad Sci 110: E2420-E2427.

Wood JG, Rogina B, Lavu S, Howitz K, Helfand SL, Tatar M, Sinclair D. 2004. Sirtuin activators mimic caloric restriction and delay ageing in metazoans. Nature 430: 686-689.

Wyse CA, Coogan AN, Selman C, Hazlerigg DG, Speakman JR. 2010. Association between mammalian lifespan and circadian free-running period: The circadian resonance hypothesis revisited. Biol Lett 6: 696-698.

Xu F, Gao Z, Zhang J, Rivera CA, Yin J, Weng J, Ye J. 2010. Lack of SIRT1 (mammalian Sirtuin 1) activity leads to liver steatosis in the SIRT1 ${ }^{+/-}$mice: A role of lipid mobilization and inflammation. Endocrinology 151: 2504-2514. 
Yeung F, Hoberg JE, Ramsey CS, Keller MD, Jones DR, Frye RA, Mayo MW. 2004. Modulation of NF-каB-dependent transcription and cell survival by the SIRT1 deacetylase. EMBO J 23: 2369-2380.

You M, Cao Q, Liang X, Ajmo JM, Ness GC. 2008. Mammalian sirtuin 1 is involved in the protective action of dietary saturated fat against alcoholic fatty liver in mice. $J$ Nutr 138: 497-501.

Zhang QJ, Wang Z, Chen HZ, Zhou S, Zheng W, Liu G, Wei YS, Cai H, Liu DP, Liang CC. 2008. Endothelium-specific overexpression of class III deacetylase SIRT1 decreases atherosclerosis in apolipoprotein E-deficient mice. Cardiovasc Res 80: 191-199.

Zhang G, Li J, Purkayastha S, Tang Y, Zhang H, Yin Y, Li B, Liu G, Cai D. 2013. Hypothalamic programming of systemic ageing involving IKK- $\beta$, NF-кB and GnRH. Nature 497: $211-$ 216.

Zhong L, D'Urso A, Toiber D, Sebastian C, Henry RE, Vadysirisack DD, Guimaraes A, Marinelli B, Wikstrom JD, Nir T, et al. 2010. The histone deacetylase Sirt6 regulates glucose homeostasis via Hif1 $\alpha$. Cell 140: 280-293.

Zhou S, Chen HZ, Wan YZ, Zhang QJ, Wei YS, Huang S, Liu JJ, Lu YB, Zhang ZQ, Yang RF, et al. 2011. Repression of P66Shc expression by SIRT1 contributes to the prevention of hyperglycemia-induced endothelial dysfunction. Circ Res 109: 639-648.

Zhou X, Fan LX, Sweeney WE Jr, Denu JM, Avner ED, Li X. 2013. Sirtuin 1 inhibition delays cyst formation in autosomal-dominant polycystic kidney disease. I Clin Invest 123: 3084-3098.

$\mathrm{Zu}$ Y, Liu L, Lee MY, Xu C, Liang Y, Man RY, Vanhoutte PM, Wang Y. 2010. SIRT1 promotes proliferation and prevents senescence through targeting LKB1 in primary porcine aortic endothelial cells. Circ Res 1060: 1384-1393. 


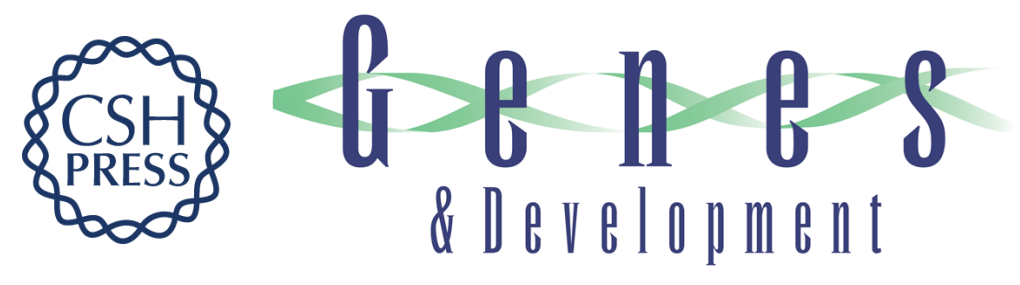

\section{Calorie restriction and sirtuins revisited}

Leonard Guarente

Genes Dev. 2013, 27:

Access the most recent version at doi:10.1101/gad.227439.113

References This article cites 187 articles, 62 of which can be accessed free at: http://genesdev.cshlp.org/content/27/19/2072.full.html\#ref-list-1

Creative This article, published in Genes \& Development, is available under a Creative Commons Commons License (Attribution-NonCommercial 3.0 Unported), as described at License http://creativecommons.org/licenses/by-nc/3.0/.

Email Alerting Receive free email alerts when new articles cite this article - sign up in the box at the top Service right corner of the article or click here.

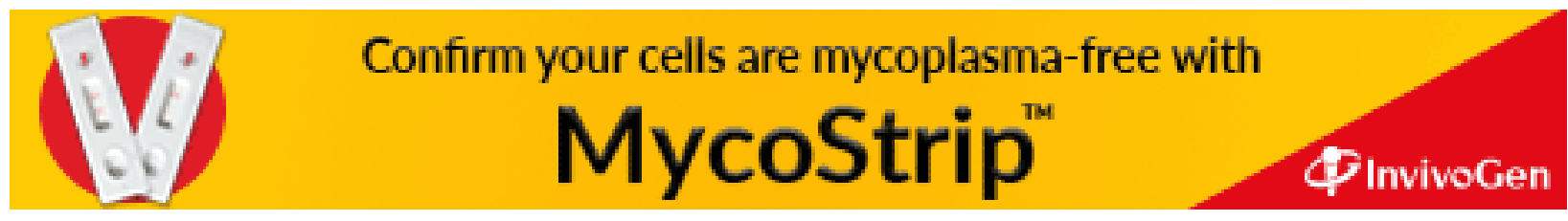

